\title{
Two Dimensional Hydrodynamic Modelling of Northern Bay of Bengal Coastal Waters
}

\author{
Misbah Uddin1", Jahir Bin Alam1, Zahirul Haque Khan², G. M. Jahid Hasan1, \\ Tauhidur Rahman 1 \\ ${ }^{1}$ Department of Civil and Environmental Engineering, Shahjalal University of Science and Technology, Sylhet, \\ Bangladesh \\ ${ }^{2}$ Coast, Port and Estuary Division, Institute of Water Modelling, Dhaka, Bangladesh \\ Email: * mun cee@yahoo.co.uk
}

Received 7 July 2014; revised 16 August 2014; accepted 6 September 2014

Copyright (C) 2014 by authors and Scientific Research Publishing Inc.

This work is licensed under the Creative Commons Attribution International License (CC BY).

http://creativecommons.org/licenses/by/4.0/

(c) (†) Open Access

\begin{abstract}
Mathematical models have advancement to a point where they are considered to be an effective tool for simulating natural phenomena in coastal regions. This paper discusses the development of Bay of Bengal Model (BoBM), updating of the model with the recent bathymetry and shore line of islands and coastline and upgrading from rectangular grid to finer size of mesh grids by using latest version of MIKE21 FM modeling system. This model is very useful for the hydrodynamic study in the coastal region of Bangladesh. The article also presents the model set-up, boundary conditions and few calibration results of the model. The model applications clearly show the variation of the flow structure, their speed and direction separately for monsoon and dry season around the model area which covers the northern part of Bay of Bengal.
\end{abstract}

\section{Keywords}

2D Model, Calibration, Water Level, Discharge, Current Speed, Current Direction, Residual Flow

\section{Introduction}

The Bay of Bengal, including the Andaman Sea and Malacca Strait, lies roughly between latitudes $5^{\circ} \mathrm{N}$ to $23^{\circ} \mathrm{N}$ and longitudes $79.8^{\circ} \mathrm{E}$ to $102^{\circ} \mathrm{E}$. It is bordered by eastern coast of Srilanka and India on the west, Bangladesh coast to the north, western coast of Myanmar (formerly known as Burma) and north western part of Malay Peninsula to the east [1]. The mathematical model presented in this study includes the area of northern part of the Bay of Bengal from latitude $17.65^{\circ}$ to the coast of Bangladesh and longitude $94.57^{\circ}$ at Gwa beach to $83.28^{\circ}$ at

${ }^{*}$ Corresponding author.

How to cite this paper: Uddin, M., Alam, J.B., Khan, Z.H., Hasan, G.M.J. and Rahman, T. (2014) Two Dimensional Hydrodynamic Modelling of Northern Bay of Bengal Coastal Waters. Computational Water, Energy, and Environmental Engineering, 3, 140-151. http://dx.doi.org/10.4236/cweee.2014.34015 
Vishakhapatnam.

The estuarine along the $710 \mathrm{~km}$ coastline of Bangladesh is a very dynamic coastal system [2]. Here, one of the world's greatest rivers the Lower Meghna River finds its way to the Bay of Bengal. The Lower Meghna conveys the combined flows of the Brahmaputra, the Ganges and the Upper Meghna. The sediment discharge from the Lower Meghna River is the highest [3] and the water discharges the third highest, of all river systems in the world [4]. Erosion and accretion rates are high and the area is periodically subjected to severe storms and cyclones.

The hydrodynamic factors that are playing dominant role in morphological development along coast line of Bangladesh are; enormous volume of river water flow, sediment transport, strong tidal and wind actions, wave, salinity and cyclonic storm surge. These hydrodynamic factors and their interactions shape the morphology of the estuary. A complicated interplay between the forces of the river, tide and the waves creates a complex pattern of sediment displacement in the estuary. Large quantities of sediment are transferred continuously towards the shallow coastal region of Bangladesh. The displacement of sediment is a part of continuous process of the estuarine-landscape striving to achieve dynamic equilibrium between morphology and the continuously changing river discharge conditions and tidal flows.

Keeping this background in mind, in order to have the essential comprehension of the flow pattern in the Bay of Bengal which is highly affected by above mentioned natural and many other man-made activities, the authors realized to have an accurate hydrodynamic model. Scientifically based mathematical modelling is an efficient tool for establishing hydraulic and morphological conditions, reliable evaluation of coastal development plan for maximizing the benefit integrating the coastal systems incorporating upstream and downstream hydraulic conditions.

\section{Literature Review}

The earliest 2D Model for Bay of Bengal was developed under the project Cyclone Shelter Preparatory Study, CSPS during 1996 to 1998 [5]. The Model was later updated by Surface Water Modelling Center, SWMC during the project Meghna Estuary Study, MES in 2001 [6].

Jacobsen et al. (2002) [7] performed numerical simulations through the two-dimensional MIKE 21 model during the Meghna Estuary Study (MWR, 1997) [8] and obtained a counterclockwise circulation with a northward flow in the Sandwip Channel and a southward flow in the Tetulia River and in the area from Hatia to Sandwip. During the study it was also observed that the residual circulation, to some extent, traps the river water inside the Meghna Estuary and thus increases the residence time, which is one of the reasons for the relatively low salinity in the estuary even during the dry season. During the study wind stress was considered not to influence the residual currents of the Meghna Estuary significantly but earlier another numerical investigation in the Northern Bay of Bengal by Ali (1995) established that south-westerly monsoon wind may increase water level in the estuary and create back water effects in the rivers. Potemra (1991) also studied the seasonal circulation in the upper Bay of Bengal.

Under the Estuary Development Programme, EDP in 2010 [9], Institute of Water Modelling, IWM has updated the BoBM with the recently surveyed hydro-morphological data and latest satellite imagery. During EDP, the model has been upgraded from rectangular mesh to flexible mesh using MIKE 21FM modelling system. Present study mainly focuses the development and improvement of model obtained during EDP study.

This article is outlined as follows: an elaborated introduction is followed by heading methodology where scientific background and detail about the data and boundary used in the model are described. Then results and discussion are pointed out and finally, the conclusions are extracted.

\section{Methodology}

A mathematical model usually describes a system by a set of variables and a set of equations that establish relationships between the variables. The BoBM is a two dimensional one layer (depth integrated) hydrodynamic model based on MIKE21FM modeling software. It is the basic module of the entire MIKE 21 system. MIKE 21 HD simulates the water level variations and flows in response to a variety of forcing functions resolved on a rectangular or triangular grid covering the area of interest when provided with the bathymetry, bed resistance coefficients, wind field, hydrographic boundary conditions etc. The module solves the vertically integrated equations of continuity and conservation of momentum in two horizontal dimensions. 


\subsection{Main Equations}

The hydrodynamic module in the MIKE 21 Flow Model FM (MIKE 21 HD, FM) is a general numerical modeling system for the simulation of water levels and flow in estuaries, bay and coastal water areas. It simulates unsteady two dimensional flows in one layer (vertically homogeneous) fluids and has been applied in a 2-D model development of Bay of Bengal.

The following equations, the conservation of mass and momentum integrated over the vertical, describe the flow and water level variations:

The continuity equation is:

$$
\frac{\partial \zeta}{\partial t}+\frac{\partial p}{\partial x}+\frac{\partial q}{\partial y}=0
$$

The momentum equation in $x$-direction is:

$$
\frac{\partial p}{\partial t}+\frac{\partial}{\partial x}\left(\frac{p^{2}}{h}\right)+\frac{\partial}{\partial y}\left(\frac{p q}{h}\right)+g h \frac{\partial \zeta}{\partial x}+\frac{g p \sqrt{p^{2}+q^{2}}}{C^{2} \cdot h^{2}}-\frac{1}{\rho_{w}}\left[\frac{\partial}{\partial x}\left(h \tau_{x x}\right)+\frac{\partial}{\partial y}\left(h \tau_{x y}\right)\right]-\Omega_{q}-f V V_{x}+\frac{h}{\rho_{w}} \frac{\partial}{\partial x}\left(p_{a}\right)=0
$$

The momentum equation in $y$-direction is:

$$
\frac{\partial q}{\partial t}+\frac{\partial}{\partial y}\left(\frac{q^{2}}{h}\right)+\frac{\partial}{\partial x}\left(\frac{p q}{h}\right)+g h \frac{\partial \zeta}{\partial y}+\frac{g q \sqrt{p^{2}+q^{2}}}{C^{2} \cdot h^{2}}-\frac{1}{\rho_{w}}\left[\frac{\partial}{\partial y}\left(h \tau_{y y}\right)+\frac{\partial}{\partial x}\left(h \tau_{x y}\right)\right]+\Omega_{p}-f V V_{y}+\frac{h}{\rho_{w}} \frac{\partial}{\partial x y}\left(p_{a}\right)=0
$$

where $p$ and $q\left(\mathrm{~m}^{3} / \mathrm{s} / \mathrm{m}\right)$ are fluxes in $x$ - and $y$-directions respectively, $t(\mathrm{~s})$ is time, $x$ and $y(\mathrm{~m})$ are Cartesian coordinates, $h(\mathrm{~m})$ is water depth, $d$ is time varying water depth $(\mathrm{m}), g\left(9.81 \mathrm{~m} / \mathrm{s}^{2}\right)$ acceleration due to gravity, $\zeta$ $(\mathrm{m})$ is the sea surface elevation, $C$ is a Chezy resistance parameter $\left(\mathrm{m}^{1 / 2} / \mathrm{s}\right), f(V)$ wind friction factor, $V, V_{x}, V_{y}$ wind speed and components in $x$ - and $y$-directions $(\mathrm{m} / \mathrm{s}), \Omega$ is Coriolis parameter which is latitude dependent $\left(\mathrm{s}^{-1}\right), P_{a}$ is atmospheric pressure $\left(\mathrm{kg} / \mathrm{m} / \mathrm{s}^{2}\right), \rho_{w}$ density of water $\left(\mathrm{kg} / \mathrm{m}^{3}\right), \tau_{x x}, \tau_{x y}, \tau_{y y}$ components of effective shear stress.

\subsection{Data Used for Model Development}

The modelling study has been devised in combination with data analysis and numerical modelling. The two dimensional (2-D) flexible mesh model (MIKE21 FM) has been applied for hydro-morphological investigation around the study area. Data on recent bathymetry, sediment concentration and hydrometrics of the estuary have been utilized for updating and re-calibrating the existing Bay of Bengal model and establishing baseline conditions.

Data surveyed and collected by different agencies of Bangladesh Government like BWDB, CDSPIII for executing different projects in the coastal region have been compiled in Table 1.

\subsubsection{Bathymetric Data}

The bathymetry data over the entire Meghna Estuary was surveyed and the data has been analysed. BWDB has checked the consistency of Bench Mark values that were used during bathymetric survey and corrected the bathymetry accordingly. MIKE-C Map which is global data base for water depth or water-land boundaries was

\begin{tabular}{|c|c|c|c|}
\hline Data & Source & Name of Study & Period \\
\hline \multirow[t]{2}{*}{ Bathymetry } & BWDB & Meghna Estuary Study II [6] & 2000 \\
\hline & CDSP III & Survey and Modelling Study of Sandwip-Urirchar-Noakhali Cross-Dam(s) [11] & 2009-10 \\
\hline Water Level & CDSP III & Survey and Modelling Study of Sandwip-Urirchar-Noakhali Cross-Dam(s) [11] & 2009-10 \\
\hline Discharge & CDSP III & Survey and Modelling Study of Sandwip-Urirchar-Noakhali Cross-Dam(s) [11] & 2009-10 \\
\hline
\end{tabular}
used to generate land level data in the deep Bay of Bengal.

Table 1. List of data collected from secondary sources. 


\subsubsection{Water Level Data}

Water level data are used to estimate the variation of water depth over the year, tidal characteristics and also to calibrate the hydrodynamic model. Water level observations have been carried out with pressure gauge over 24 hours at half an hour interval. All water level data are referred to Public Works Department (PWD) datum. The measured water level data at various locations have been plotted and considerable inconsistencies have been found. Bench mark error as well as processing error may have caused these inconsistencies in water level data. The consistent water level data have been used for calibration of the model.

\subsubsection{Discharge Data}

Discharge measurement was carried out for 13 hours with one hour interval in the Lower Meghna River (at Kaliganj), Hatiya Channel, East Shahbazpur Channel, West Shahbazpur Channel, the Tetulia River and Sandwip Channels. These data have been utilised for calibration.

\subsection{Mesh Generation and Bathymetry Development}

Objective of mesh generation is to divide the whole model area in to a number of individual triangular flexible cells to perform the computation. To generate mesh, shoreline is essential. Shoreline can be extracted from satellite images using ARC View/ARC GIS or from MIKE-C Map. In case of BoB model shoreline is extracted from satellite images. Area included inside the shoreline represents a polygon (Figure 1). In case of BoB model one polygon should not be used. If coarser resolution is used for whole area then the estuary cannot be represented properly. Again if finer resolution is used to represent the Meghna estuary properly then the total number of computational points will be increased and simulation time will be higher. To avoid this situation total area is divided into four polygons of different resolution as shown Figure 2. The resolution varies from $5400 \mathrm{~m} \times 5400$ $\mathrm{m}$ and $1800 \mathrm{~m} \times 1800 \mathrm{~m}$ in the Bay of Bengal, through $600 \mathrm{~m} \times 600 \mathrm{~m}$ in the Meghna Estuary and $200 \mathrm{~m} \times 200$ $m$ in the areas of special interest.
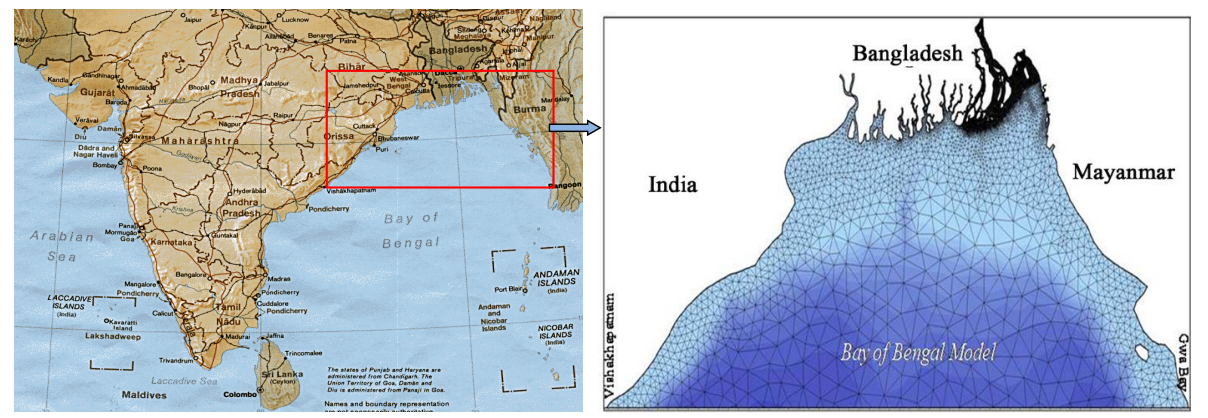

Figure 1. Model domain enclosed by shoreline of the Bay of Bengal.

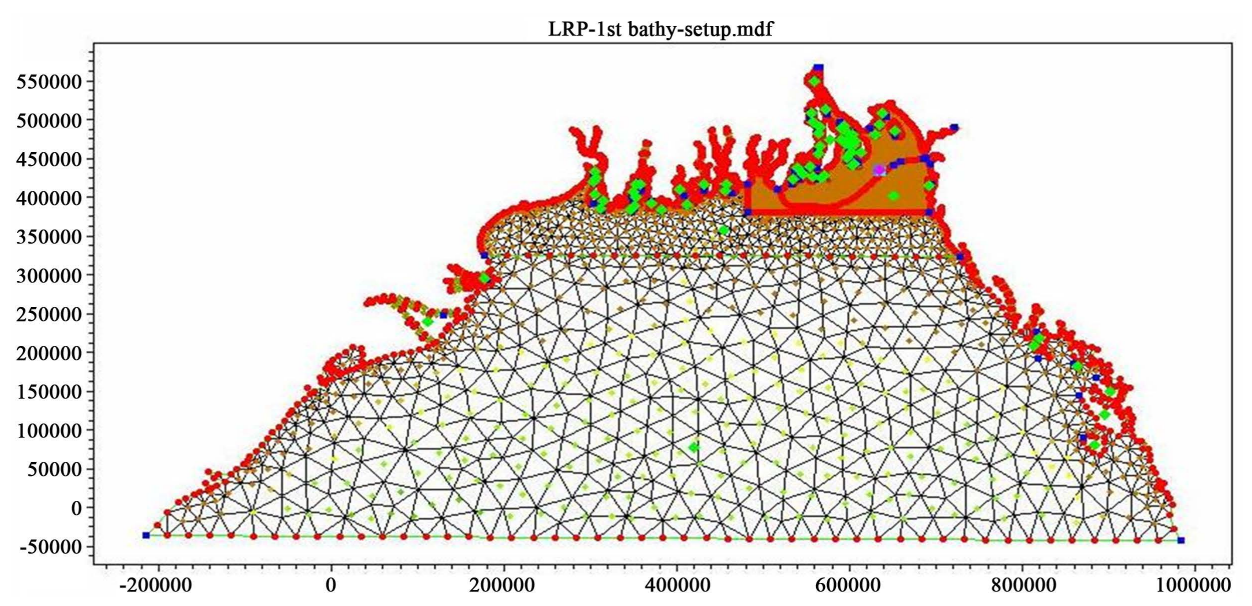

Figure 2. Different polygon and their mesh resolution in model domain. 
For bathymetry generation the measured and generated land level data were incorporated with the mesh and by applying the interpolation method, elevation in each and every point of the modeled area were calculated. The generated bathymetry is shown in Figure 3.

\subsection{Boundary Generation}

There are two open boundaries in the model, one is in the Lower Meghna River at Chandpur, which is northern boundary and another one is in the Bay of Bengal that is southern boundary shown in Figure 3. Observed water level at Chandpur station has been used in the northern boundary. Predicted or generated water level using Global Tide Model of two stations namely Vishakhapatnam (India) and Gwa Bay (Myanmar) was used for south boundary.

\section{Results and Discussion}

The two-dimensional hydrodynamic model of the Bay of Bengal have been calibrated against water level and discharge at different locations comparing the model results with field measurement to make the model performance to a satisfactory level. The validation has been made only with the available data for the year 2008. The model is based on the surveyed data of 2009-2010 and calibrated with water level and discharge measurements of 2009-2010 and found good agreement. Hydrodynamic simulation has been made for one month for both the dry and monsoon seasons in order to establish the hydraulic characteristics for low and high discharges. Locations of calibration areas have been presented in Figure 4.

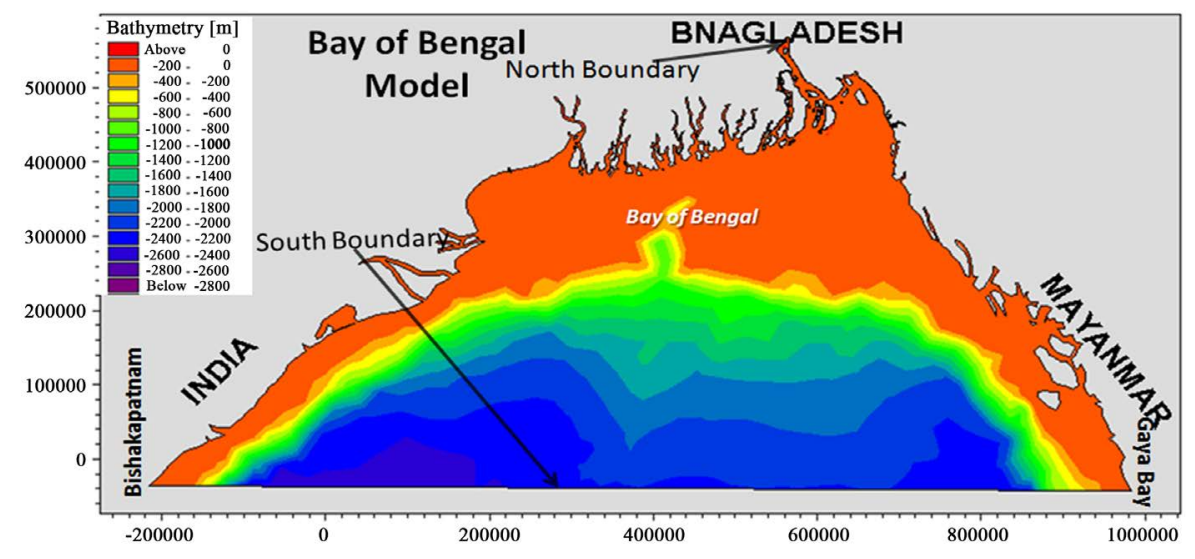

Figure 3. Bathymetry and open boundaries of BoB Model.

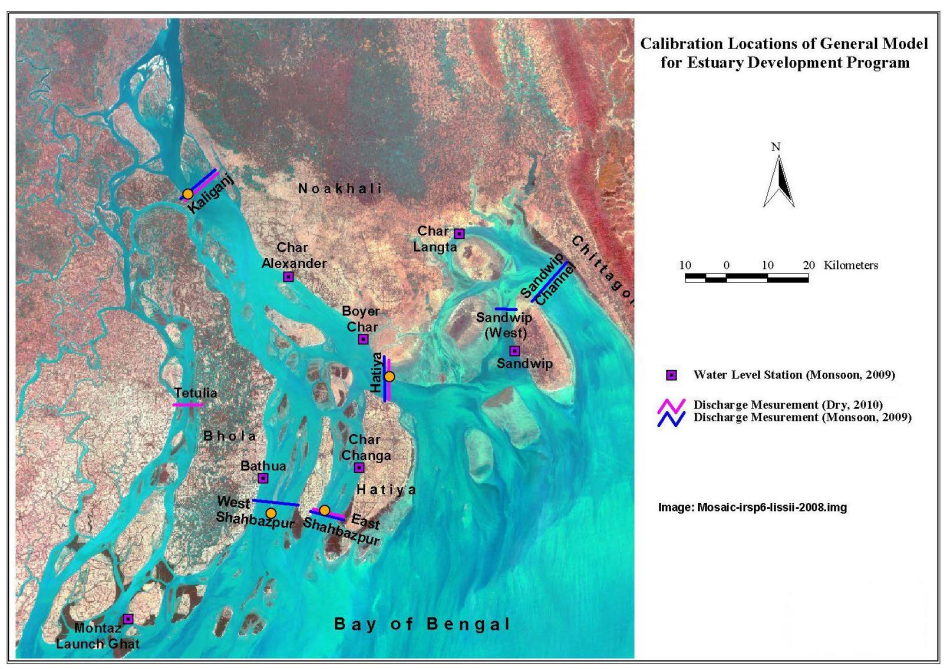

Figure 4. Calibration locations of Bay of Bengal Model. 
Some plots of these calibration points have been shown in the following figure. Figure 5(a) and Figure 5(b) shows the calibration against water level at Boyer Char and Sandwip for wet season. Calibrations against observed discharge during wet and dry season at Monpura-Jahajmara (East Shabhazpur Channel) have been shown in Figure 6(a) and Figure 6(b). Figure 7(a) and Figure 7(b), represents discharge calibration at Bhola-Monpura and at Nairpur during wet season 2009 and dry season 2010 respectively.

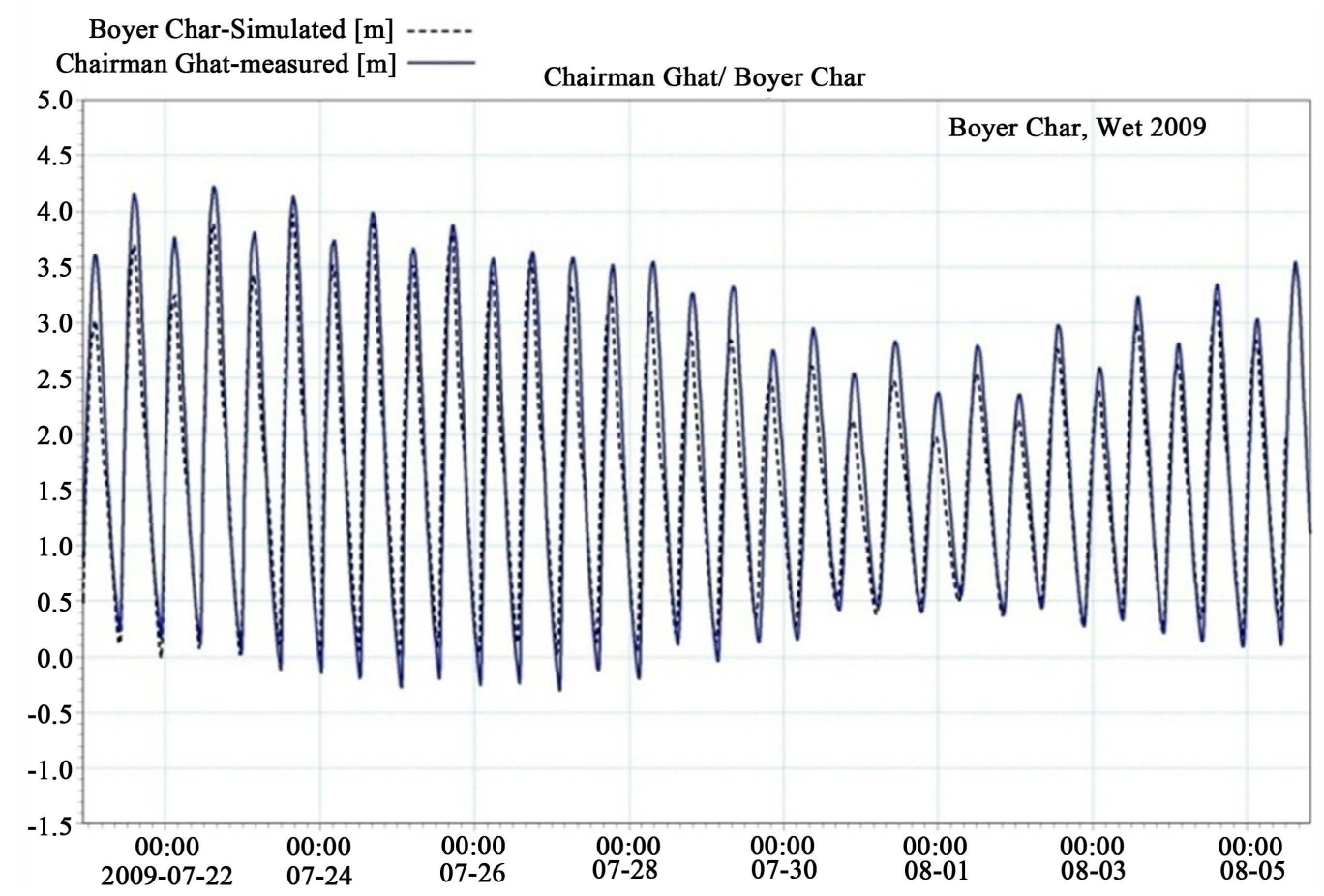

(a)

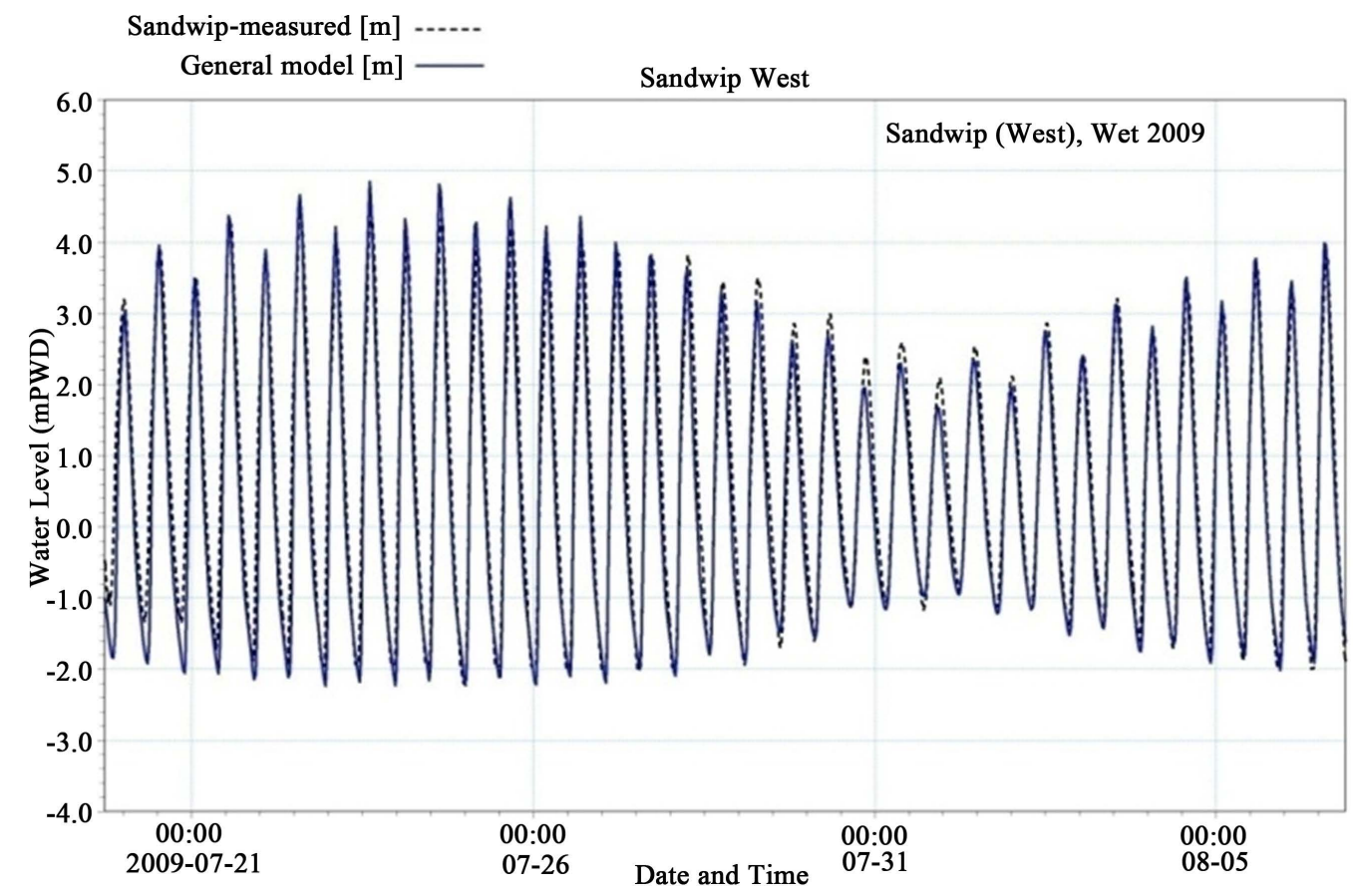

(b)

Figure 5. Calibration results of Bay of Bengal Model on water level. 


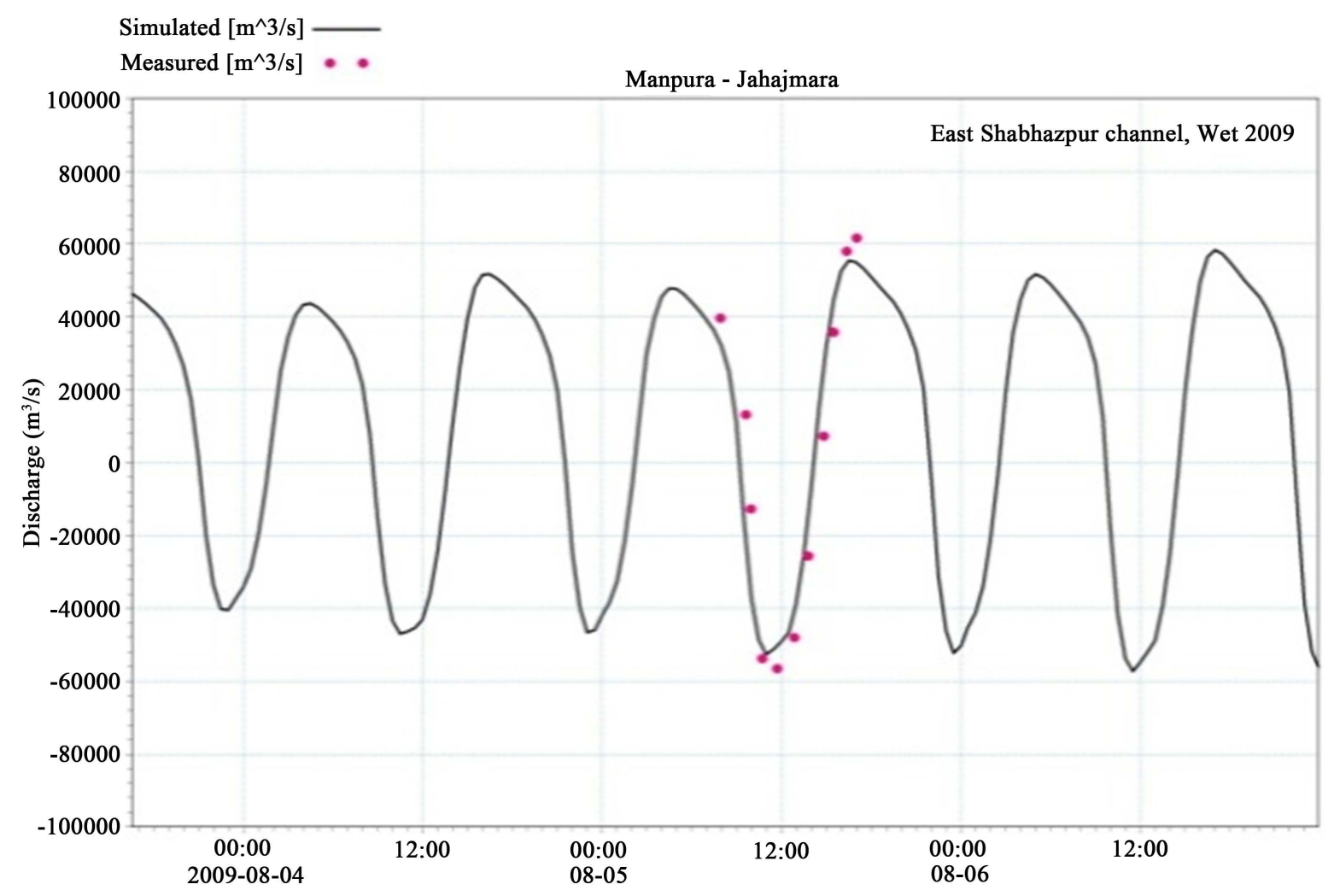

(a)

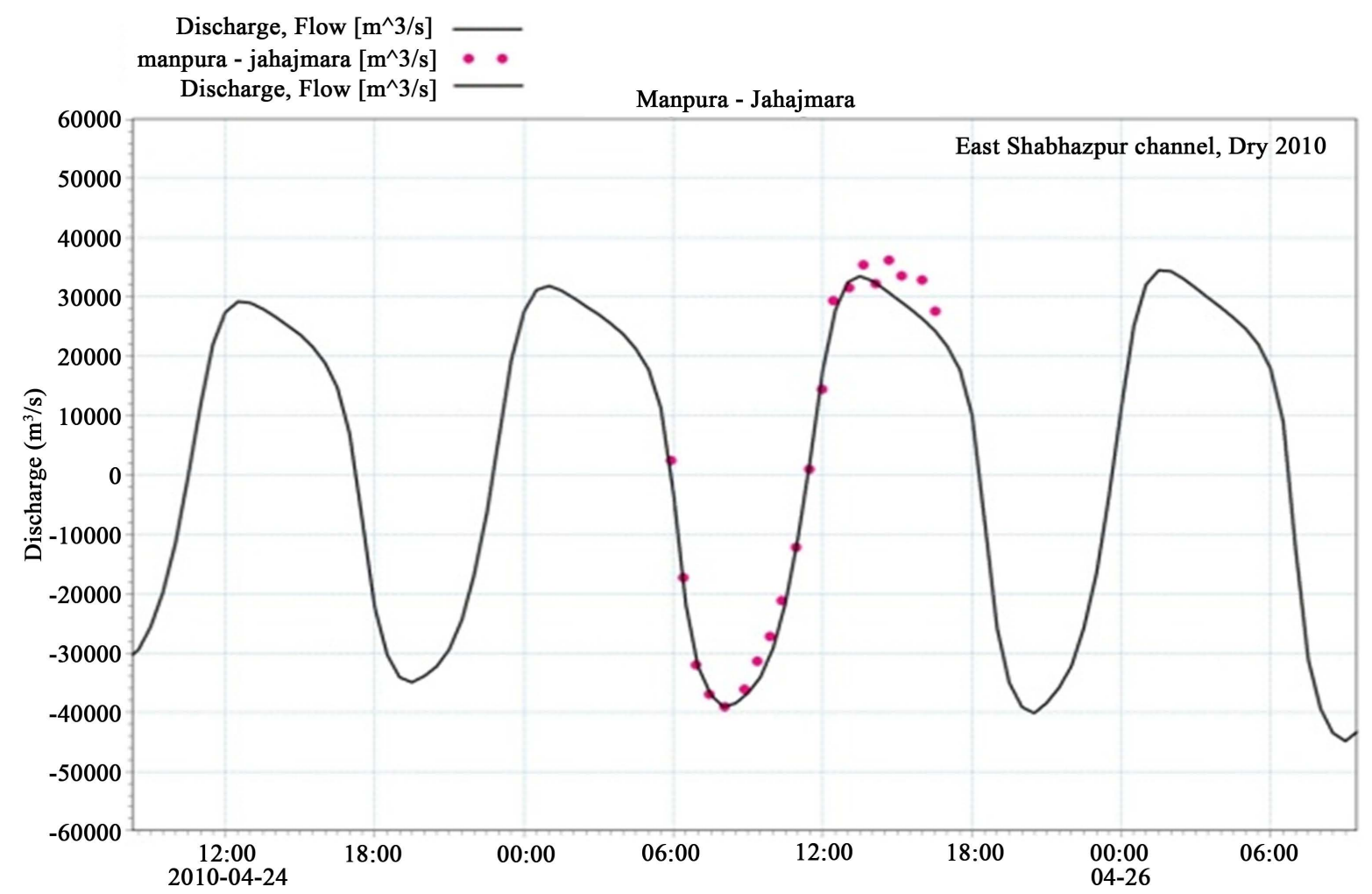

(b)

Figure 6. Calibration against discharge of Bay of Bengal Model. 


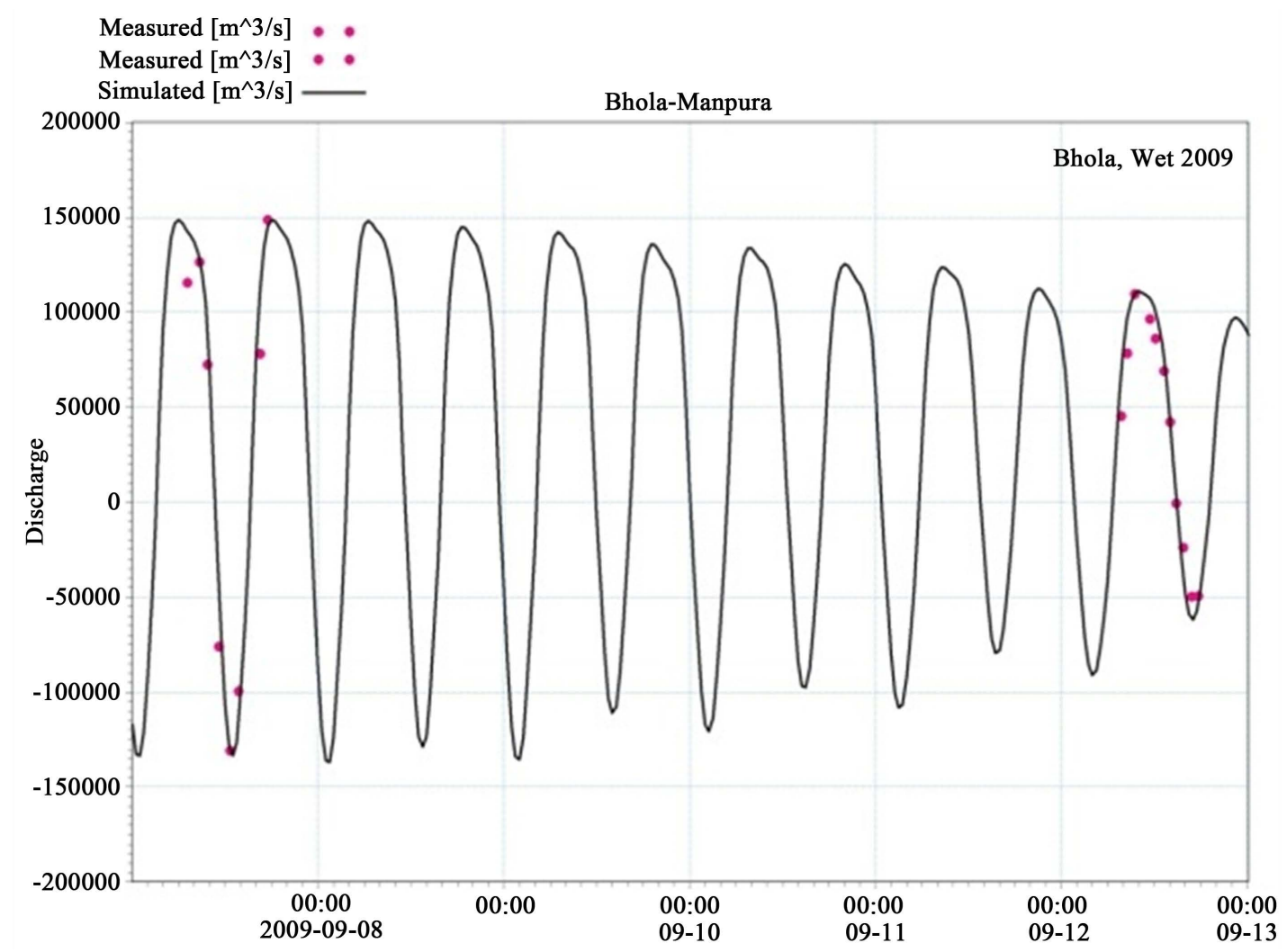

(a)

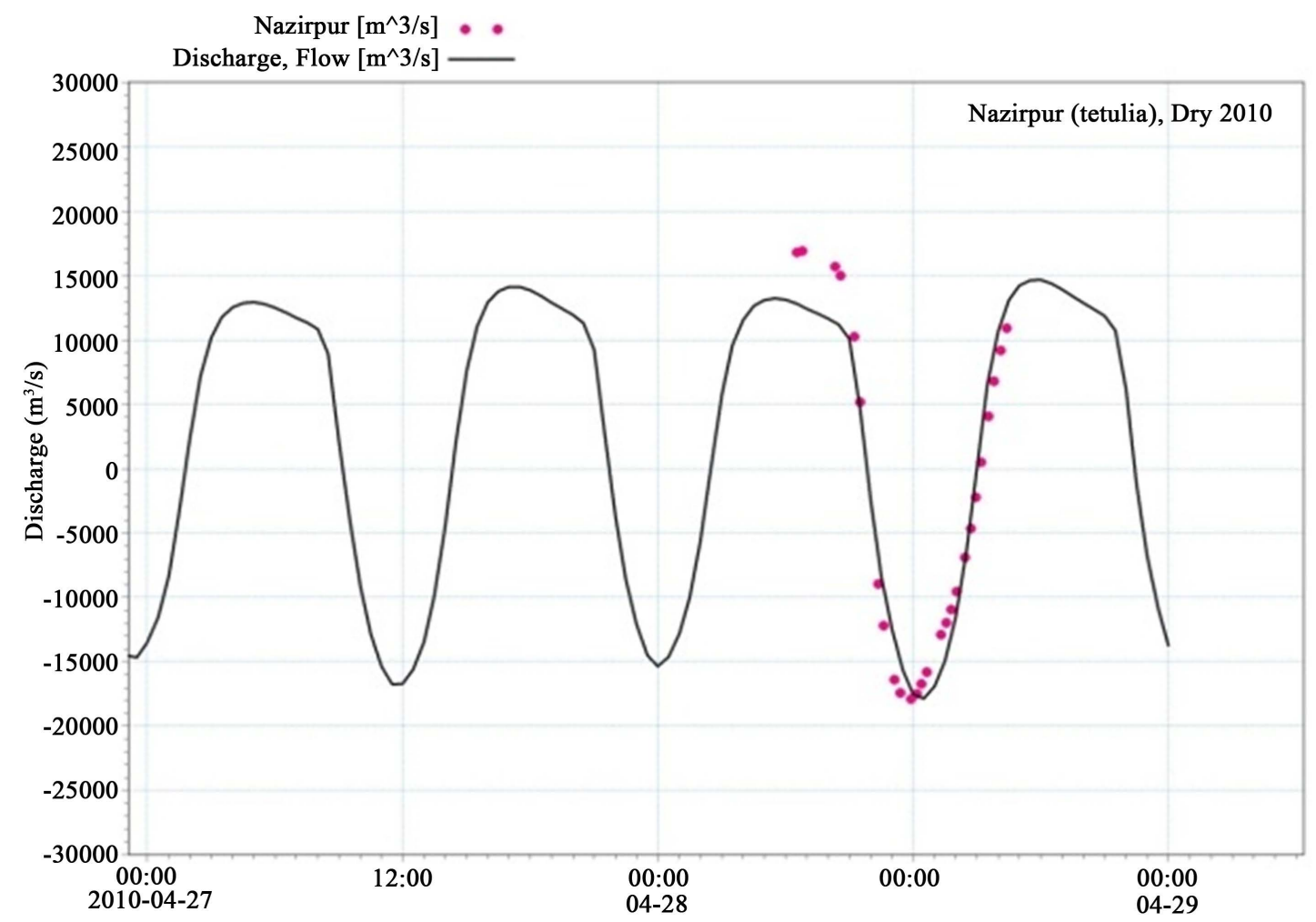

(b)

Figure 7. Calibration against discharge of Bay of Bengal Model. 
All these calibration plots show good amplitude and phase agreement between the model results and observed data.

As a result of interactions of different hydrodynamic forces active in the estuary some changes like siltation in channel bed, shoreline erosion, shifting of thalweg and finally shifting of channels are occurred in the estuary. The hydraulic conditions of the Meghna estuary such as residual flow, mean current speed and tidal meeting point in the different channel of Meghna Estuary has been established and analyzed for dry and monsoon season under this study using the results of the Bay of Bengal Model.

During dry season upland fresh water flow into the Bay through the Lower Meghna River is very much lower than that of monsoon season. Tidal action becomes stronger and dominates water flow pattern in the estuary. Lowest velocities of about $0.25-1.0 \mathrm{~m} / \mathrm{s}$ are found in the upper part of the lower Meghna River during dry period, where the tidal action is less dominant (Figure 8).

The estuary becomes morphologically very dynamic during monsoon. The upland flow is enormous during monsoon and the mean high water is considerably higher than during dry season. The distribution of flow and water level in the different channels of the estuary are governed by river discharge, the tide and the wind speed. The maximum depth average current speeds of about $1.75 \mathrm{~m} / \mathrm{s}$ are found mainly in the West Shabhazpur Channel, north Hatiya channel and north of Urirchar, i.e. in the Bamni channel during monsoon. Most of the accretion and erosion occurs during monsoon. Current speed and direction during monsoon is shown in Figure 9.

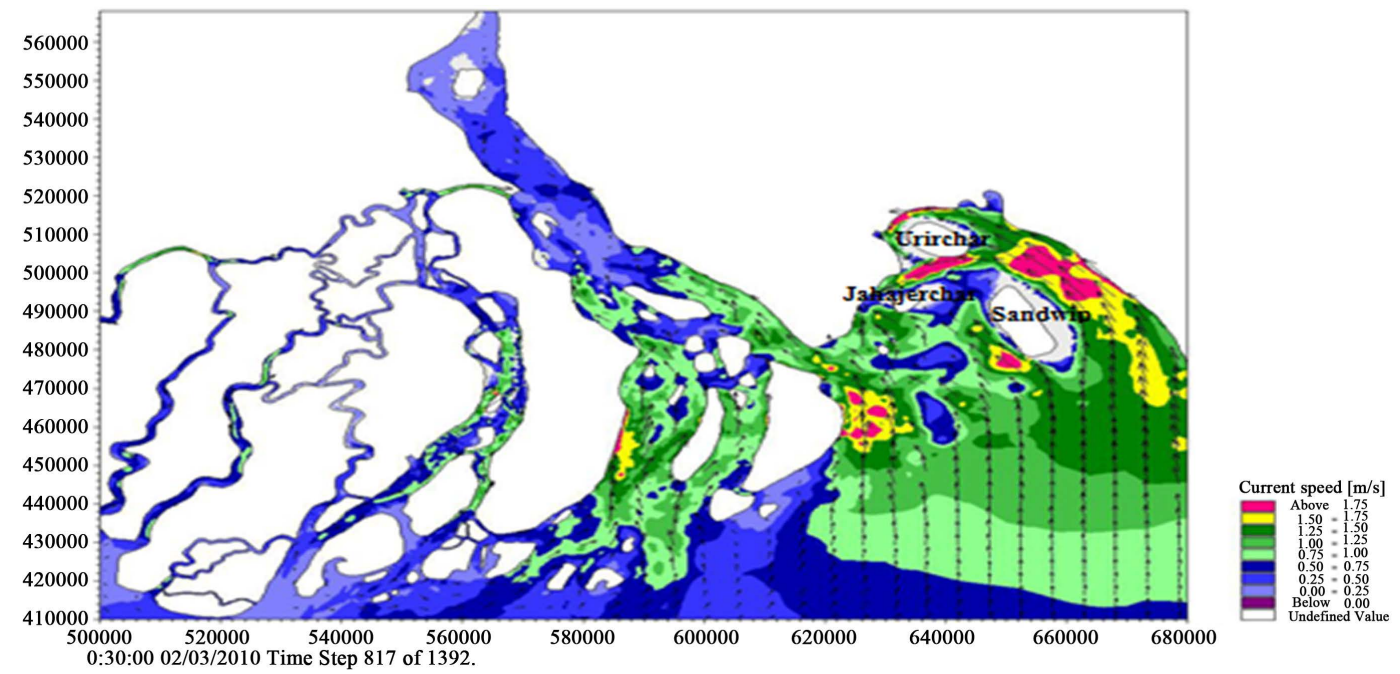

Figure 8. 2D map of flow speed/direction, covering one tidal cycle, every 2 hours (dry period).

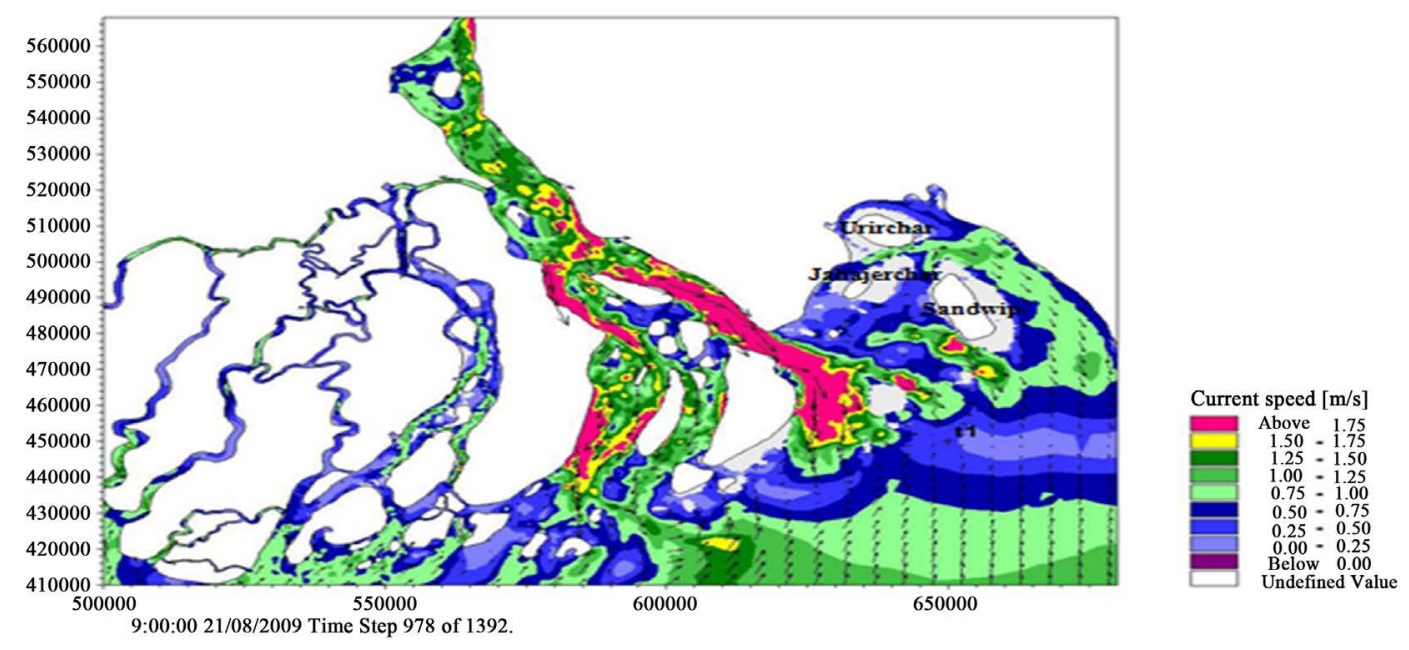

Figure 9. 2D map of flow speed/direction, covering one tidal cycle, every 2 hours (monsoon). 
The residual flow has been established based on the simulation results of one month covering spring and neap tides both for dry and monsoon season. Simulation result shows a net water flow out of the Meghna estuary through West Shabhazpur channel and easterly flow outside the estuary during dry season. A prominent anticlockwise circulation is prevailing around the Sandwip Island, which is mainly forced by tide. In the Sandwip channel, the residual anti-clockwise circulation during monsoon is similar to the circulation during dry season, which implies the area is dominated by tide both in dry and monsoon seasons. The net anti-clockwise circulation traps the sediment in this area. The net flow in between Sandwip and Hatia Island is influenced by the river discharge. The residual flow and mean current speed is shown in Figure $\mathbf{1 0}$ and Figure $\mathbf{1 1}$ for dry and wet season respectively.

Simulation results shows three tidal meeting points in the Sandwip, Jahazerchar and Urirchar area; one in the channel between Urirchar and Char Clark, other meeting point is in the channel between Jahazer Char and Noakhali coast near Char Bayejid and another meeting point in the channel between Jahazer Char and Sandwip, shown in Figure 12. Model results show that in this area the change of flow direction takes place over a very short distance and rapidly, which is in good agreement with the field observations.

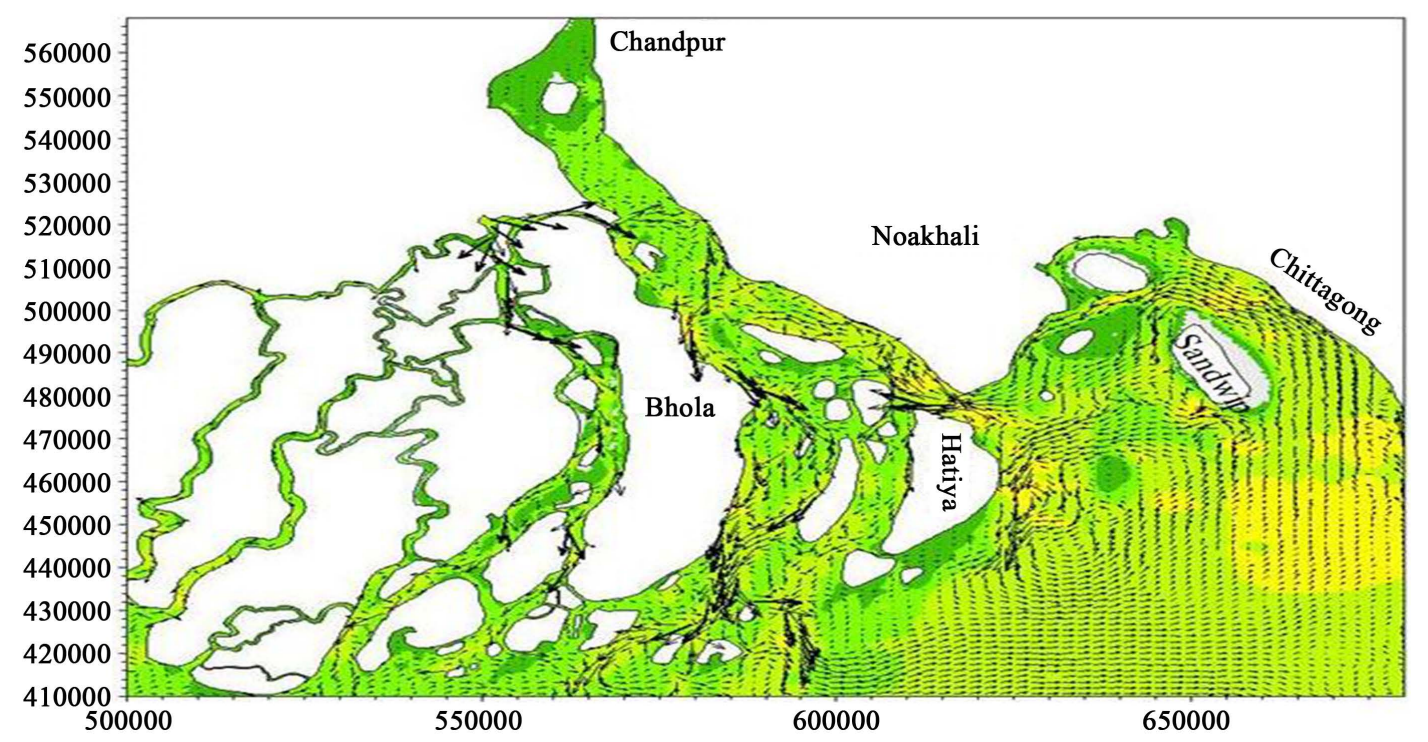

Figure 10. Residual flow pattern in the Meghna Estuary in Dry season (February, 2010).

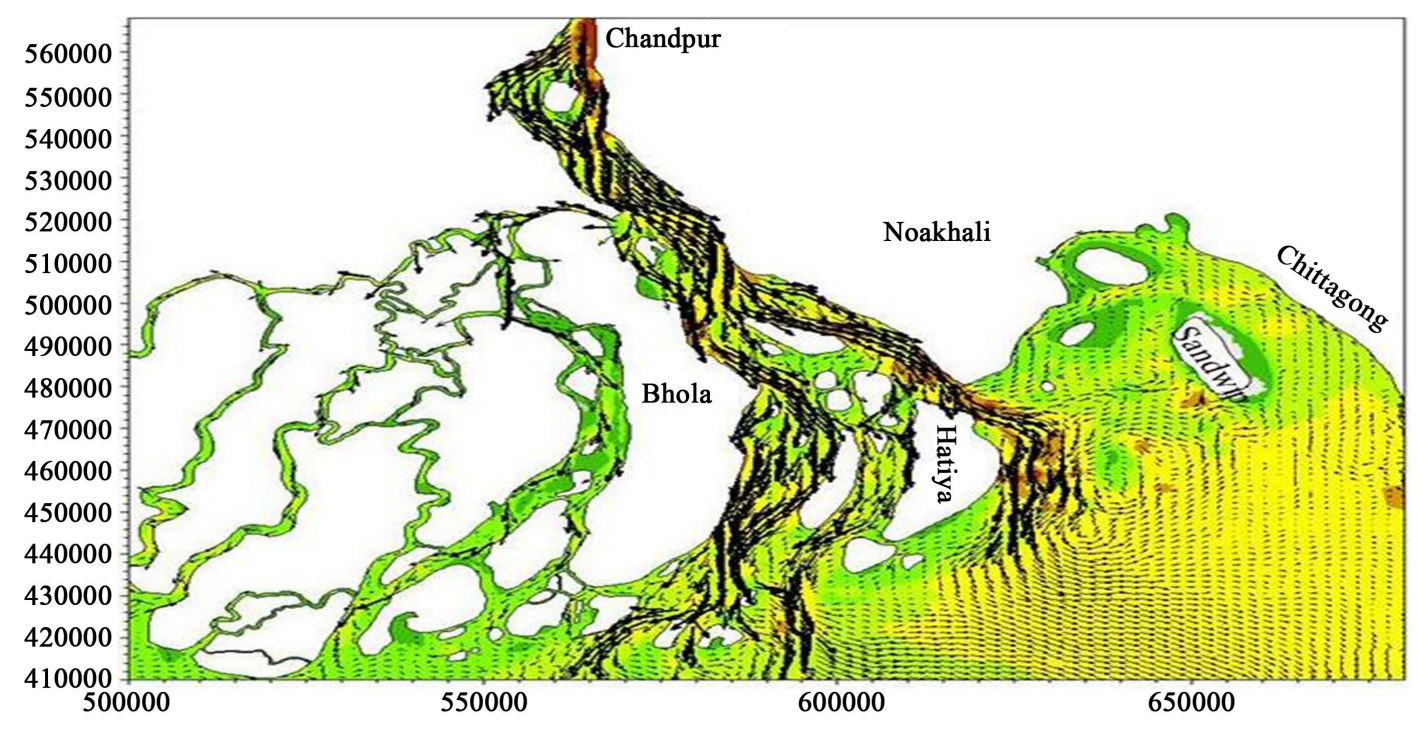

Figure 11. Residual flow pattern in the Meghna Estuary in Wet season (August, 2009). 


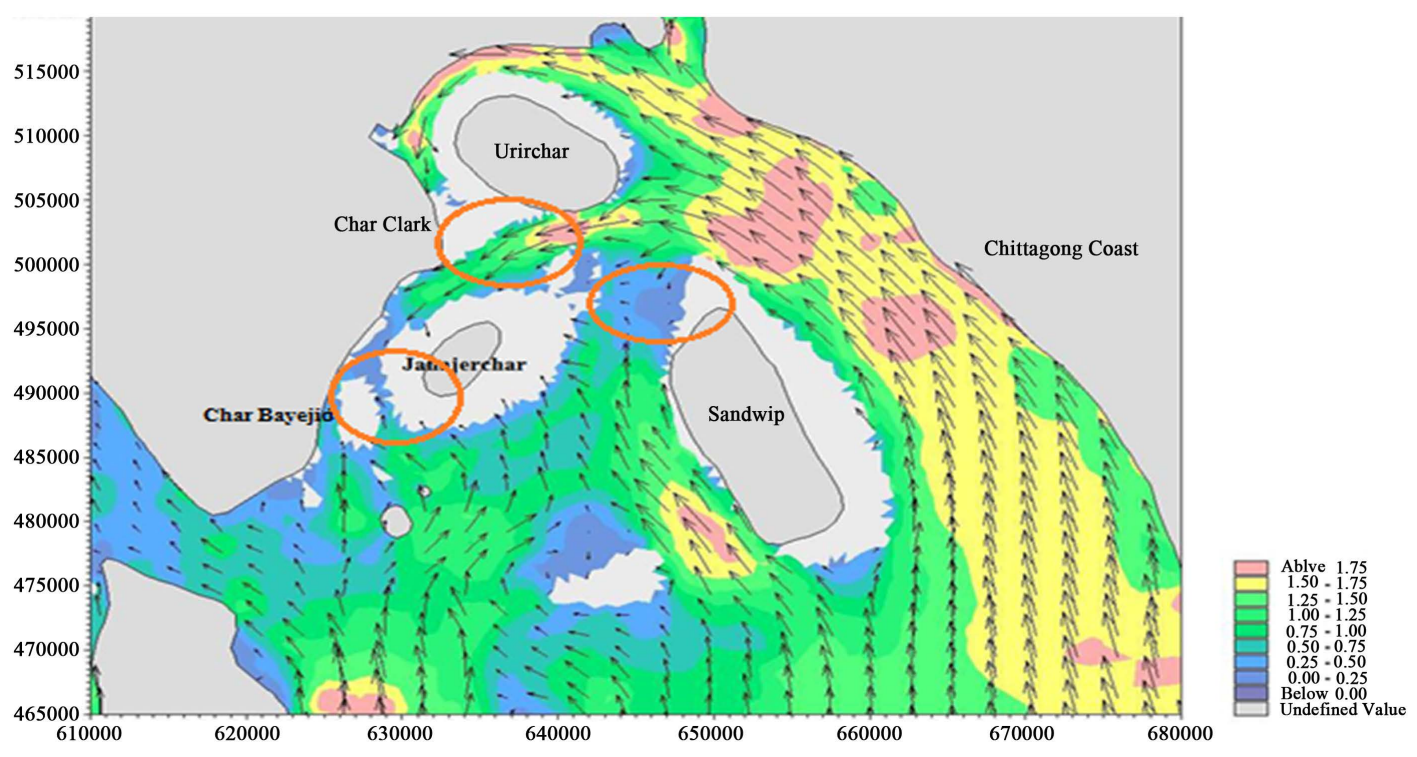

Figure 12. Tidal Meeting Points in Sandwip-Urirchar-Noakhali area (Tidal meeting points are marked with red circles).

\section{Conclusions}

During the initial development of BoB model, observed water level has been used in the upstream boundary and predicted tide has been used in the downstream boundary. To obtain optimum result, an attempt may be taken to extend the upstream boundary towards $20 \mathrm{~km}$ up where rating curve is available for generating discharge and hence the present boundary stations may be used as a calibration point. Use of discharge data at upstream boundary will reduce the boundary effect and improve the model performance.

Sediment movement in the Meghna estuary is very important since about 1.5 billion tons of sediment from Ganges-Brahmaputra-Meghna basin is discharged to the Bay of Bengal through this estuary. It is possible to reclaim land artificially or enhance the natural accretion process by proper management of this huge amount of sediment. Moreover for avoiding unwanted siltation efficient management of sediment is also necessary. To understand the sediment movement phenomena, to investigate the accretion and erosion process in the estuary and to calculate sediment budget, a morphology model or mud transport model along with this hydrodynamic model should be developed.

Furthermore, a sensitivity analysis can also be made to access the sensitiveness of different parameters such as roughness, critical shear stress for erosion and deposition, time step and viscosity. In addition, with more measurement stations data available, the BoBM can be calibrated and validated more effectively to increase its robustness and prediction accuracy.

\section{Acknowledgements}

The authors gratefully acknowledge the support and contributions of the Institute of Water Modelling (IWM), Dhaka. The works presented in this article is based on the work, carried out during "Estuary Development Programme” project execution in IWM.

\section{References}

[1] Sindhu, M. (2012) Numerical Modelling of Tides and Storm Surges in the Bay of Bengal. Ph.D. Thesis, Goa University, Goa.

[2] Koen, W.D. (2011) Moving Coastlines, Emergence and Use of Land in the Ganges-Brahmaputra-Meghna Estuary. The University Press, Dhaka, 2 p.

[3] Coleman, J.M. (1969) Brahmaputra River: Channel Process and Sedimentation. Sedimentary Geology, 3, 129-239. http://dx.doi.org/10.1016/0037-0738(69)90010-4

[4] Milliman, J.D. (1991) Flux and Fate of Fluvial Sediment and Water in Coastal Seas. In: Mantoura, R.F.C., Martin, 
J.-M. and Wollast, R., Eds., Ocean Margin Processes in Global Change, John Willey and Sons Ltd., Chichester, 69-89.

[5] CSPS (1998) Cyclone Shelter Preparatory Study, Stage I: Feasibility Phase. Final Report. Mathematical Modelling of Cyclone-Surge and Related Flooding. European Commission, Directorate General External Economic Relations. Technical Unit for Asia Centre, Planning Commission, Dhaka.

[6] S.W.M.C. (2001) Two-Dimensional Model of the Meghna Estuary. 2nd Update Report, Submitted to MES by Surface Water Modelling Center.

[7] Jakobsen, F., Azam, M.H. and Kabir, M.M. (2002) Residual Flow in the Meghna Estuary on the Coastline of Bangladesh. Estuarine, Coastal and Shelf Science, 55, 587-597. http://dx.doi.org/10.1006/ecss.2001.0929

[8] MWR (1997) Meghna Estuary Study, Salinity Distribution in the Estuary. Ministry of Water Resources, Bangladesh Water Development Board, Technical Note MES-004. Report by DHV Consultants BV for DGIS/DANIDA and GOB.

[9] EDP (2010) Estuary Development Programme, Final Report, Submitted to Ministry of Water Resources, Bangladesh Water Development Board by Institute of Water Modelling.

[10] IWM (2006) Hydraulic Modelling Study in Connection with Feasibility Study for Hatiya-Nijhum Dwip Cross-Dam Project.

[11] IWM (2009) Survey and Modelling Study of Sandwip-Urirchar-Noakhali Cross-Dam(s). Final Report, Submitted to Char Development and Settlement Project-III (CDSP-III) by Institute of Water Modelling. 
Scientific Research Publishing (SCIRP) is one of the largest Open Access journal publishers. It is currently publishing more than 200 open access, online, peer-reviewed journals covering a wide range of academic disciplines. SCIRP serves the worldwide academic communities and contributes to the progress and application of science with its publication.

Other selected journals from SCIRP are listed as below. Submit your manuscript to us via either submit@scirp.org or Online Submission Portal.
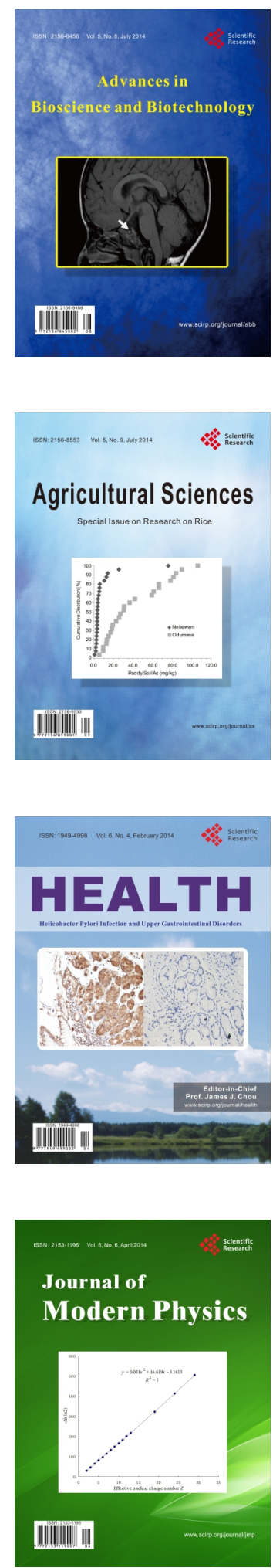
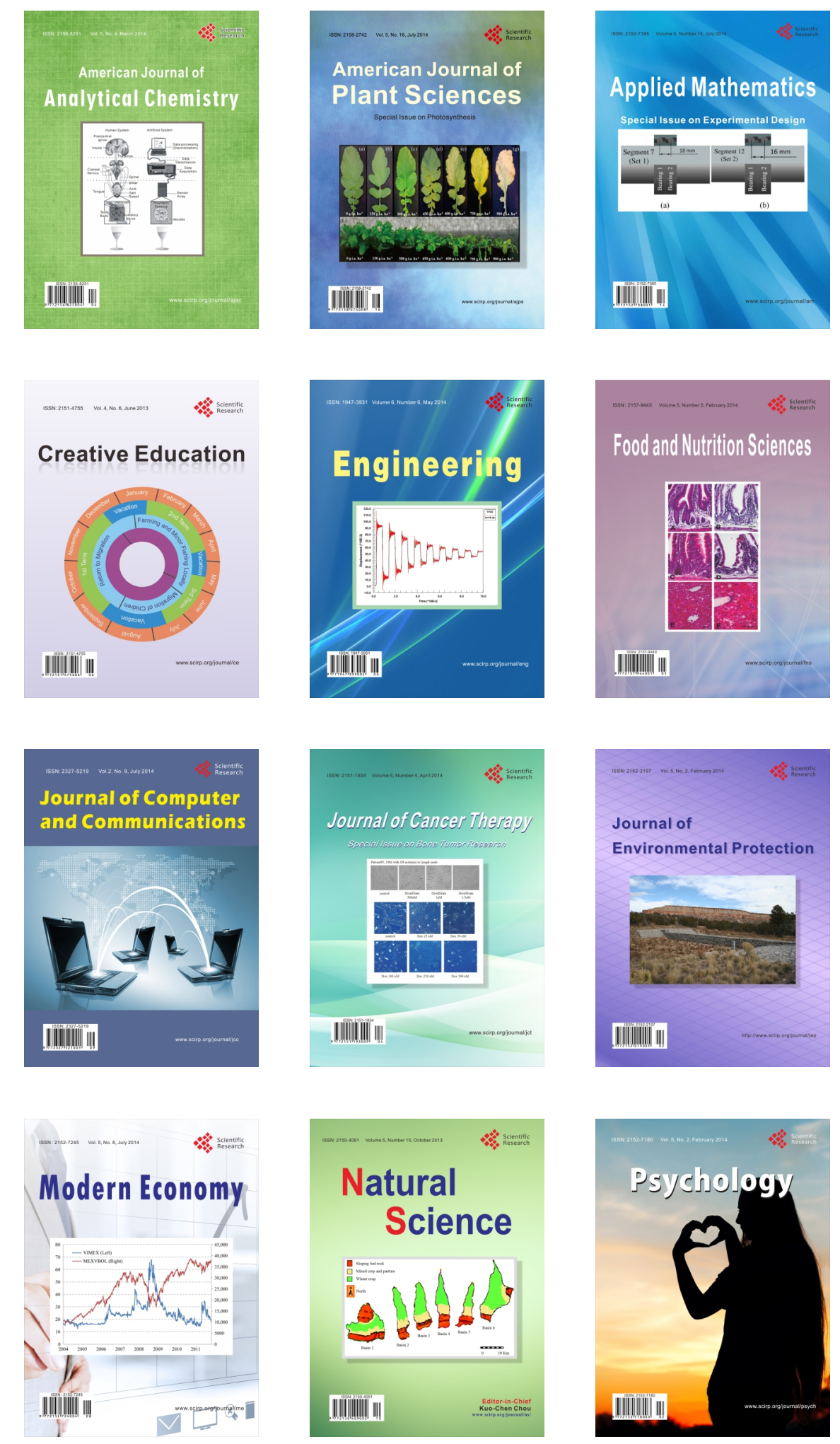